\title{
Comparative study of the effects of black or white hail nets on the fruit quality of 'Golden Delicious' apples
}

\author{
Veronica Ordóñez ${ }^{1}$, Francisco Javier Molina-Corral ${ }^{1}$, Claudia Lizeth Olivas-Dorantes ${ }^{1}$, \\ Juan Luis Jacobo-Cuéllar ${ }^{2}$, Gustavo González-Aguilar ${ }^{3}$, Miguel Espino ${ }^{1}$, David Sepulveda ${ }^{1}$ \\ and Guadalupe Isela Olivas ${ }^{1, \star}$ \\ 1 Centro de Investigación en Alimentación y Desarrollo CIAD, Cuauhtémoc, Chihuahua, México \\ 2 Instituto Nacional de Investigaciones Forestales, Agrícolas y Pecuarias (INIFAP), Campo Experimental Sierra de Chihuahua, \\ Cuauhtémoc, Chihuahua, México \\ 3 Centro de Investigación en Alimentación y Desarrollo CIAD, Hermosillo, Sonora, México
}

Received 26 March 2015 - Accepted 27 April 2016

\begin{abstract}
Introduction. The use of hail nets to protect apples during development and maturation on the tree is very common in Mexico. This practice can cause changes in fruit quality and aroma composition. The effects of the hail net color on the quality and aroma volatile production of apple cultivated in Chihuahua, Mexico, were evaluated. Materials and methods. 'Golden Delicious' apple trees were covered with white or black hail nets. Apple samples were harvested weekly from August to early October, and analyzed for weight, axial and equatorial diameters, color $\left({ }^{\circ} \mathrm{Hue}\right)$, firmness, total soluble solids (TSS), acidity, ethylene production (EC), and aroma volatile composition. The photosynthetically available radiation (PAR) was measured every ten days under each hail net and outside. Results and discussion. Apple quality was affected by hail net color. Black hail nets delayed maturation and quality development of apples by one week when compared with white hail nets. The PAR values were $18 \%$ lower under black nets than under white nets. Quality parameters at commercial harvest (162 days after full bloom) showed that whitenet apples presented 7\% lower firmness, $11.1 \%$ less acidity, $8.3 \%$ higher TSS and a more developed yellow color, when compared with black-net apples. In addition, white-net apples presented higher contents of the main aroma compounds (in $\mu \mathrm{g} \mathrm{L}^{-1}$ ) 1-hexanol (8.09 vs. 4.38), 2-methyl-1-butanol (6.24 vs. 2.65), and 2-methyl-butyl acetate (0.47 vs. 0.16). At the same maturity stage (beginning of the climacteric rise), no difference was found between white- and black-net apples in TSS, acidity, firmness and aromatic compounds. Conclusion. Hail net functionality goes beyond protecting orchards from hail damage; hail net color affects the apple maturation rate, quality and aroma volatile production.
\end{abstract}

Keywords: Mexico / apple / Malus domestica / netting in agriculture / photosynthetically available radiation / aroma volatiles

Résumé - Étude comparative des effets de filets anti-grêle noirs ou blancs sur la qualité des pommes 'Golden Delicious'. Introduction. L'utilisation de filets anti-grêle pour protéger les pommes au cours du développement et de la maturation sur l'arbre est bien connue au Mexique. Cette pratique est toutefois susceptible de causer des changements de qualité et de composition aromatique des fruits. Les effets de la couleur du filet anti-grêle ont été étudiés sur la qualité des arômes volatils de pommes produites à Chihuahua, au Mexique. Matériel et méthodes. Des pommiers 'Golden Delicious' ont été couverts d'un filet anti-grêle de couleur, soit blanc soit noir. Des échantillons de pommes ont été collectés chaque semaine à partir du mois d'août jusqu'au début octobre, et les paramètre suivants ont été analysés : poids d'un fruit, diamètre axial et équatorial, couleur $\left({ }^{\circ} \mathrm{Hue}\right)$, fermeté, teneur en matières solubles (TSS), acidité, production d'éthylène (EC), et composition en arômes volatils. Le rayonnement photosynthétique disponible (PAR) a été mesuré tous les dix jours sous chaque filet anti-grêle et à l'extérieur. Résultats et discussion. La qualité des pommes a été affectée par la couleur du filet anti-grêle. Le filet noir a retardé la maturation et la qualité du développement des pommes d'une semaine par rapport aux pommes sous filet blanc. Les valeurs de PAR étaient $18 \%$ inférieures sous filet

\footnotetext{
^ Corresponding author: golivas@ciad.mx
} 
noir de celles sous filet blanc. Les paramètres de qualité à la récolte commerciale (162 jours après pleine floraison) ont montré que les pommes sous filet blanc présentaient une fermeté $7 \%$ moindre, une acidité $11,1 \%$ inférieure, un TSS 8,3\% plus élevé, et une couleur jaune plus développée que les pommes sous filet noir. En outre, les pommes sous filet blanc ont présenté des teneurs plus élevées pour les principaux composés aromatiques (en pg L $\mathrm{L}^{-1}$ ) : 1-hexanol (8,09 vs 4,38), 2-méthyl-1-butanol $(6,24$ vs 2,65) et 2-méthyl-butyl acétate d'éthyle $(0,47$ vs 0,16$)$. Au même stade de maturité (début de la montée climatérique), aucune différence n'a été observée entre les pommes sous filet blanc ou noir concernant les matières solubles, l'acidité, la fermeté du fruit et les composés aromatiques. Conclusion. La fonctionnalité des filets anti-grêle va au-delà de la protection des vergers contre les dommages causés par la grêle ; la couleur des filets affecte le degré de maturation de la pomme, la production et la qualité de ses arômes volatils.

Mots clés : Mexique / pommier / Malus domestica / filet agricole / rayonnement photosynthétique disponible / composé aromatique volatil

\section{Introduction}

Hailstorms are very common in Northern Mexico [1], causing significant apple damage with the subsequent economic loss [2,3]. For this reason, growers are compelled to use hail nets during the growing season, to protect apples against damage [1]. However, the technical basis for the use of hail nets in this region has been established through a trial-anderror strategy, using mainly black polyethylene hail nets and, to a lesser extent, white nets. The reason for choosing a black net color has been merely dependent on price and durability, ignoring the potential impact of net color on apple quality [4].

Hail net color may affect apple quality by modifying the incidence of photosynthetically active radiation (PAR), leading to an altered environment beneath the netting. Some studies have shown that apples grown under hail nets suffer from delayed ripening, in addition to inferior quality, such as smaller fruit size, less coloration, less firmness and less sugar [1,5-9]. Hail netting could also affect the aroma volatile compounds responsible for flavor, the main quality attribute of 'Golden Delicious' apples produced in Northern Mexico [10].

The effect of hail netting on the apple fruit quality may depend on the net color; therefore, the objective of this study was to determine whether the hail net color affects the quality and aroma volatile production of 'Golden Delicious' apple fruits grown in Northern Mexico, during the maturation on the tree.

\section{Materials and methods}

\subsection{Plant material, hail net treatment}

The experimental plot was located in a commercial orchard in Cuauhtémoc, Chihuahua, Mexico (28 $23^{\prime} 51.43^{\prime \prime}$, $\left.106^{\circ} 49^{\prime} 05.79^{\prime \prime} \mathrm{W}\right)$ at $2,062 \mathrm{~m}$ above sea level. Twenty-fiveyear-old apple trees (Malus $\times$ domestica Borkh. cv. Golden Delicious) on standard rootstock, spaced $3.0 \mathrm{~m} \times 5.0 \mathrm{~m}$ in real squares, were used for this experiment, with a net cover system consisting of white or black netting. A total of 60 trees were used, 30 trees covered with white nets, and 30 trees covered with black nets. Tree rows were oriented east-west. Three rows with black net and three rows with white net were used as buffer trees between the netting treatments. Uncovered apples were not evaluated, due to the high risk of hailstorms and the subsequent economic losses for growers. Apples were harvested and compared weekly during ripening from 134 to 175 days after full bloom (dafb), from the southwest side of each tree. Maturity parameters and quality attributes were evaluated as described below. Apples were also compared at the commercial harvest date, established by the grower at $162 \mathrm{dafb}$ for both treatments.

\subsection{Hail net specifications}

The black and white hail nets were composed of colored UV-treated high-density polyethylene (HDPE) virgin resin. Both types of hail nets studied had the same number of threads per square inch, 4 double-thread warp and 6 single-thread weft per square inch. Therefore, both types of hail nets caused interference to the passage of light in exactly the same way due to the presence of HDPE white and black strands (true shadow); however, due to the presence of reflected light, which is inherent in the color differences (since black absorbs light and white reflects it), the black net presented $16 \%$ shadiness, while the white net's shadiness was $6-7 \%$. Consequently, the difference in shadiness between treatments is considered as an effect of the hail net color and it is not confounded with the effect of the "true shadow" caused by light interference of the threads in the hail net.

- Weave type: English row

- Mesh size: $5 \times 3 \mathrm{~mm}$

- Double-thread warp: 4 threads in ${ }^{-2}$

- Single-thread weft: 6 threads in ${ }^{-2}$

- Shadiness: $16 \%$ black net, $6-7 \%$ white net

- Weight: $68 \mathrm{~g} \mathrm{~m}^{-2}$

- Strand: $16 \mu \mathrm{m}$ monofilament

- Composition: black- or white-colored UV-treated highdensity polyethylene (HDPE) virgin resin

- Hail net structure: oil pipes (2.375 in. diameter, 80 schedules) set $24 \mathrm{~m}$ apart, $6.5 \mathrm{~m}$ high

- Elongation: $3 \%$

\subsection{Light interception by nets}

At the top of the canopy, for uncovered and covered trees, the photosynthetically active radiation $(\mathrm{PAR}=400-700 \mathrm{~nm}$; $\mu \mathrm{mol} \mathrm{m}{ }^{-2} \mathrm{~s}^{-1}$ ) was quantified with a LI-191SB Line Quantum Sensor (Li-Cor Inc., Lincoln, Nebraska, USA). Readings were 
taken at noon over seven sunny days from June to September. For each treatment, a total of ten readings were taken and averaged.

\subsection{Ethylene production rate}

Five fruits from each replicate were weighed and placed in 5.2- $\mathrm{L}$ jars at $20^{\circ} \mathrm{C}$. The jars were sealed for $60 \mathrm{~min}$ before measurements. The ethylene concentration was determined by a gas chromatograph (Agilent Technologies 7820A GC System) equipped with a flame ionization detector and a Hayesep Q Chromopack column (20 mesh Silica, length $1.8 \mathrm{~m}$, internal diameter $3.17 \mathrm{~mm}$ ). The chromatographic conditions were as follows: the injector temperature was $100{ }^{\circ} \mathrm{C}$. The initial temperature of the column was $60^{\circ} \mathrm{C}$ for $2 \mathrm{~min}$, and then increased to $120^{\circ} \mathrm{C}$ at a rate of $60{ }^{\circ} \mathrm{C} \mathrm{min}{ }^{-1}$, finally reaching $180{ }^{\circ} \mathrm{C}$ at a rate of $10^{\circ} \mathrm{C} \mathrm{min}^{-1}$. This final temperature was sustained for 5 additional min. The linear velocity of the helium carrier gas was $30 \mathrm{~cm} \mathrm{~s}^{-1}$. Reported ethylene values were the average of 6 replicates.

\subsection{Physicochemical measurements}

The malic acid percentage, soluble solids, color, and firmness of black-net and white-net apples were determined weekly from 134 to $175 \mathrm{dafb}$, as described by Salas et al. [11]. Apple juice obtained from 8 apples was titrated with $0.1 \mathrm{~N} \mathrm{Na}$ $\mathrm{OH}$, and acidity expressed as a percentage of malic acid. Total soluble solids in the juice were measured with a refractometer ATC-1E (Atago, Ltd, Tokyo, Japan).

For color and firmness, 10 fruits per treatment were evaluated, and two measurements made at two locations for each sample. Color was assessed using a Minolta CR-300 colorimeter (Konica Minolta, New Jersey, USA). The firmness of apples was determined with a Texture Analyzer TA-XT2i (Stable Micro Systems, YL, England), equipped with an 11-mm-diameter cylindrical probe. The maximum force needed to penetrate the peeled flesh was measured over a distance of $10 \mathrm{~mm}$ at a speed of $10 \mathrm{~mm} \mathrm{sec}^{-1}$. In addition, the weight, and axial and equatorial diameters were also measured.

\subsection{Aroma volatile production}

The concentration of volatile compounds in apples was determined by gas chromatography using the solid-phase microextraction (SPME) technique. Apple juice from eight apples per treatment was obtained with a food processor (Turmix). A 20-mL sample was placed in a 20-mL PTFE vial, frozen in liquid nitrogen and kept at $-78{ }^{\circ} \mathrm{C}$ until analysis. An aliquot of $2 \mathrm{~mL}$ of thawed apple juice was placed in a 4-mL vial containing $0.65 \mathrm{~g}$ sodium chloride and stirred, while a SPME fiber (65 $\mu \mathrm{m}$, PDMS-DVB, Supelco USA) was exposed to the headspace of the sample for $45 \mathrm{~min}$ at room temperature $\left(25^{\circ} \mathrm{C}\right)$. The fiber was desorbed by splitless injection for 12 min at $200^{\circ} \mathrm{C}$ into an Agilent Technologies 7820AGC-FID equipped with a DB-WAX column $(60 \mathrm{~m} \times 0.32 \mathrm{~mm}, 0.25-\mu \mathrm{m}$

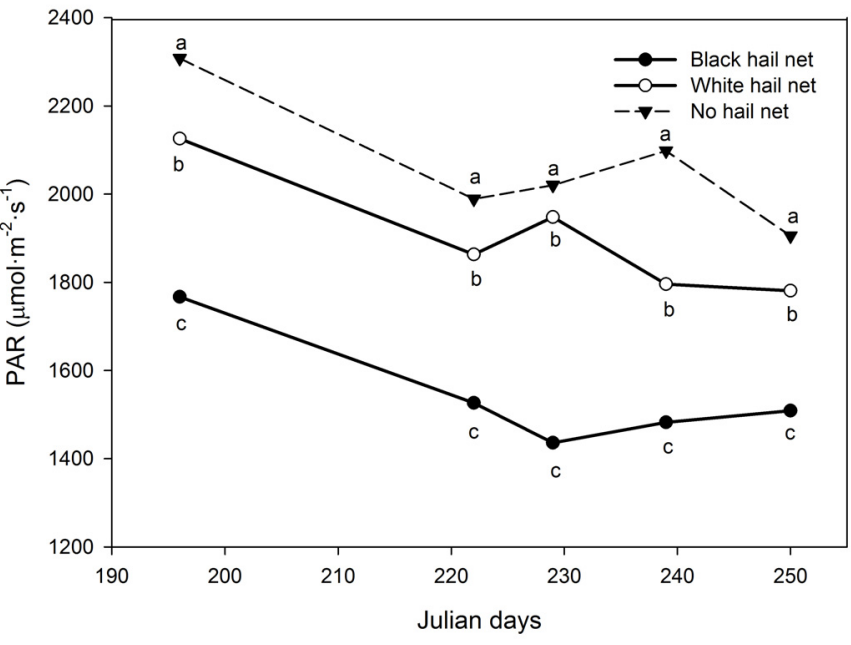

Figure 1. Effect of the hail net color on photosynthetically active radiation (PAR) incidence in the orchard. Different lower-case letters show statistical differences within the same time.

film). Chromatography conditions were as follows: the injector temperature remained constant at $200{ }^{\circ} \mathrm{C}$. The temperature of the column was $35^{\circ} \mathrm{C}$ for $5 \mathrm{~min}$, then increased to $50{ }^{\circ} \mathrm{C}$ at a rate of $2{ }^{\circ} \mathrm{C} \mathrm{min}^{-1}$, and finally reached $200{ }^{\circ} \mathrm{C}$ at a rate of $5{ }^{\circ} \mathrm{C} \mathrm{min}{ }^{-1}$, remaining that way for $10 \mathrm{~min}$. Helium was used as a carrier gas with a linear velocity of $30 \mathrm{~cm} \mathrm{~s}^{-1}$. Quantification was accomplished by external standard calibration curves integrating the peak areas. All values represent the average of triplicated samples consisting of 8 fruits each.

\subsection{Statistical analysis}

The experimental data were statistically analyzed as repeated measurements. A split-plot design was employed with hail net color (black or white) as the whole plot factor and days of apple fruit development $(134,141,148,155,162$, 169 and $176 \mathrm{dafb}$ ) as the subplot factor. Pre-planned contrasts were employed to compare specific treatments after statistical significance was established. Statistical analyses were performed using SAS ${ }^{\mathrm{MR}}$ (Statistical Analysis System, version 8.0). Statistical significance was set at the $5 \%$ level.

\section{Results and discussion}

Hail netting significantly reduced the amount of light available to the fruit (figure 1). White nets reduced photosynthetically active radiation (PAR) by an average of $6 \%$, while black hail nets reduced PAR by an average of $22 \%$. The start of the climacteric rise (initiation of the ethylene rise) was affected by hail net color, occurring at 162 days after full bloom (dafb) for apples under black nets, and at 154 dafb for apples under white nets (figure 2). Hail net color had an effect on the main apple quality parameters: acidity, color, TSS, firmness and volatile compounds, mainly after the climacteric rise (after $154 \mathrm{dafb}$ ). The results and discussion below are focused on 
Table I. Influence of net color on weight, diameter, soluble solids and malic acid percentage of 'Golden Delicious' apple during maturation.

\begin{tabular}{lcccccccc}
\hline Quality & Hail net & \multicolumn{7}{c}{ Number of days after full bloom $(\mathrm{dafb})$} \\
\cline { 3 - 9 } parameters & color & 134 & 141 & 148 & 154 & 162 & 168 & 175 \\
\hline \multirow{2}{*}{ Weight $(\mathrm{g})$} & Black & $126.8 \mathrm{a}$ & $125.2 \mathrm{a}$ & $147.1 \mathrm{a}$ & $154.9 \mathrm{a}$ & $166.8 \mathrm{aA}$ & $180.1 \mathrm{a}$ & $182.5 \mathrm{a}$ \\
& White & $110.4 \mathrm{~b}$ & $125.7 \mathrm{a}$ & $142.3 \mathrm{a}$ & $144.8 \mathrm{bB}$ & $161.5 \mathrm{a}$ & $173.8 \mathrm{~b}$ & $181.0 \mathrm{a}$ \\
\hline Axial diameter & Black & $68.2 \mathrm{a}$ & $67.4 \mathrm{a}$ & $70.7 \mathrm{a}$ & $73.1 \mathrm{a}$ & $74.6 \mathrm{aA}$ & $76.8 \mathrm{a}$ & $77.6 \mathrm{a}$ \\
$(\mathrm{mm})$ & White & $68.2 \mathrm{~b}$ & $67.2 \mathrm{a}$ & $70.4 \mathrm{a}$ & $71.3 \mathrm{bB}$ & $75.9 \mathrm{a}$ & $73.6 \mathrm{~b}$ & $77.4 \mathrm{a}$ \\
\hline Equatorial diameter & Black & $66.5 \mathrm{a}$ & $66.4 \mathrm{a}$ & $70.3 \mathrm{a}$ & $71.4 \mathrm{a}$ & $73.6 \mathrm{aA}$ & $75.9 \mathrm{a}$ & $76.4 \mathrm{a}$ \\
$(\mathrm{mm})$ & White & $64.6 \mathrm{~b}$ & $66.6 \mathrm{a}$ & $69.7 \mathrm{a}$ & $70.7 \mathrm{aB}$ & $74.7 \mathrm{a}$ & $73.3 \mathrm{~b}$ & $76.5 \mathrm{a}$ \\
\hline Soluble solids & Black & $13.6 \mathrm{a}$ & $13.7 \mathrm{a}$ & $14.7 \mathrm{a}$ & $15.5 \mathrm{a}$ & $15.5 \mathrm{aA}$ & $15.5 \mathrm{a}$ & $16.9 \mathrm{a}$ \\
$\left({ }^{\circ}\right.$ Brix $)$ & White & $14.6 \mathrm{~b}$ & $14.6 \mathrm{a}$ & $15.3 \mathrm{a}$ & $15.6 \mathrm{aA}$ & $16.9 \mathrm{~b}$ & $17.7 \mathrm{~b}$ & $17.0 \mathrm{a}$ \\
\hline Acidity & Black & $0.61 \mathrm{a}$ & $0.54 \mathrm{a}$ & $0.51 \mathrm{a}$ & $0.48 \mathrm{a}$ & $0.46 \mathrm{aA}$ & $0.43 \mathrm{a}$ & $0.42 \mathrm{a}$ \\
$(\%$ malic acid) & White & $0.58 \mathrm{a}$ & $0.55 \mathrm{a}$ & $0.48 \mathrm{a}$ & $0.44 \mathrm{bA}$ & $0.40 \mathrm{~b}$ & $0.38 \mathrm{~b}$ & $0.41 \mathrm{a}$ \\
\hline
\end{tabular}

Means with the same lower-case letter indicate no significant differences between black-net and white-net apples on the same day $(P \leqslant 0.05$, LSD Tukey's test). Means with the same capital letter indicate no significant differences between black-net and white-net apples at the beginning of the climacteric rise (162 dafb for black-net apples and 154 dafb for white-net apples - shadowed cells).

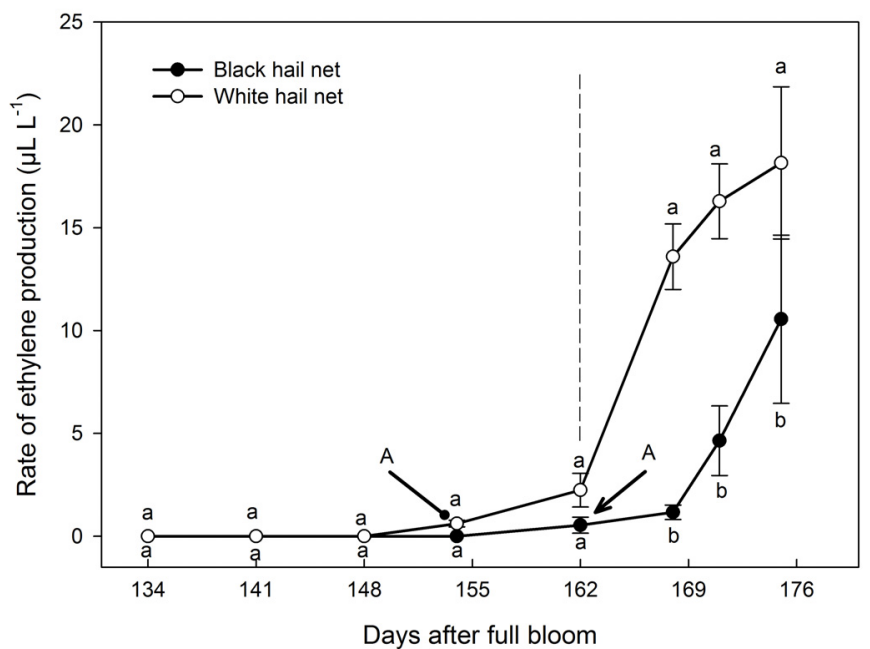

Figure 2. Effect of the hail net color on rates of ethylene production of 'Golden Delicious' apples during growth and development. The vertical bars represent means \pm SE. Different lower-case letters show statistical differences within the same harvest time; different capital letters show statistical differences in the climacteric rise (by Tukey's test, $P \leqslant 0.05)$. $\rightarrow$ climacteric rise for white-net apples (154 dafb), $\rightarrow$ climacteric rise for black-net apples (162 dafb), - - - commercial harvest (162 dafb).

comparisons between treatments at the beginning of the climacteric rise (162 and 154 dafb for black-net and white-net apples, respectively) and at commercial harvest (established by the grower at 162 dafb for both treatments).

\subsection{Weight and diameter}

In regard to weight, axial diameter and equatorial diameter, no significant differences were found between treatments when compared at the commercial harvest time (162 dafb) (table I). These results are in agreement with Smith [12], who found no effect of hail net color on 'Granny Smith' apple weight when comparing black nets, blue nets, and no netting. In a similar fashion, Widmer [5] reported that the apple size of most cultivars was not affected by black nets. However, when comparing the weight and diameter of apples at the same ripening point, at the beginning of the climacteric rise (162 and 154 dafb for black- and white-net apples, respectively), significant differences were found (table I). Apples under white nets weighed significantly less than apples covered with black nets (144 vs. $166 \mathrm{~g}$ apple ${ }^{-1}$, respectively). In the same way, apple diameters were significantly smaller in the fruits under white nets in comparison with those under black nets $(71.2 \mathrm{vs} .74 .5 \mathrm{~mm}$, and 70.6 vs. $73.6 \mathrm{~mm}$, axial and equatorial diameters, respectively). These findings suggest that while a white net accelerates the apple's physiological maturity, it does not have an impact on the weight and diameter. According to Bepete and Lakso [13], physiological maturity takes priority over physical development (size) in apple.

\subsection{Acid and soluble solid contents}

Organic acids in apples are used as substrates during the maturation process, where the concentration of malic acid, the main organic acid in apples, declines [14]. A decrease in the malic acid content in both treatments was noted as apple maturation advanced (table I). Significantly lower malic acid values were found from 154 dafb to168 dafb in apples grown under white nets compared with apples under black nets $(P \leqslant 0.05)$. When apples were compared at commercial harvest (162 dafb), white-net apples showed 13\% less malic acid than black-net apples $(P \leqslant 0.05)$. In agreement with these results, previous studies have found differences in malic acid content among apples grown under different colored hail nets; according to Solomankihin and Blanke [15], 'Pinova' and 'Fuji' apples grown under red-white hail nets were less acidic than those grown under red-black hail nets. According to Robinson et al. [16], apple acidity is slightly negatively correlated with the percentage of full sunlight. The PAR is considerably reduced by the use of black nets (an average of $22 \%$ PAR reduction) compared with white nets (an average of $6 \%$ PAR reduction) (figure 1). Contrary to these findings, previous 


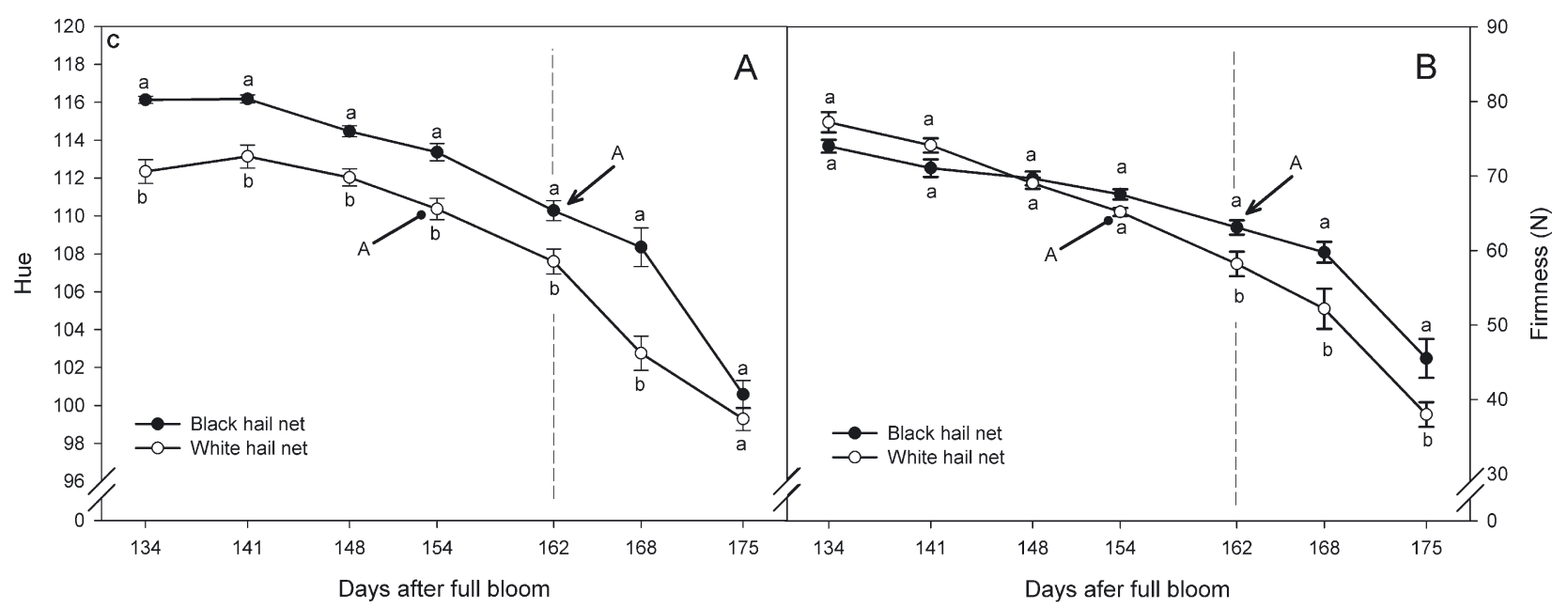

Figure 3. Effect of the hail net color on color (A) and firmness (B) of 'Golden Delicious' apples during growth and development. The vertical bars represent means \pm SE. Different lower-case letters show statistical differences within the same harvest time; different capital letters show statistical differences in the climacteric rise (by Tukey's test, $P \leqslant 0.05$ ). $\rightarrow$ climacteric rise for white-net apples (154 dafb), $\rightarrow$ climacteric rise for black-net apples (162 dafb), - - - commercial harvest (162 dafb).

reports have shown that acidity is not affected by hail net color, when studying apples at the same harvest date $[5,17,18]$.

Comparing malic acid in apples at the beginning of the climacteric rise (162 and 154 dafb for black- and white-net apples, respectively), no significant differences were observed $(P \leqslant 0.05)$. This may suggest a decrease in the time that is needed for apples to mature when a white net is used, compared with a black net. These findings suggest that there is no effect of net color on apples' acidity, when comparing them at the same maturity stage.

Soluble solids provide sweet flavor to apples [19], with fructose being the main sugar and, to a lesser extent, glucose and sucrose [20]. Total soluble solids increased as apple maturation advanced, in both treatments (table I). However, at 162 and $168 \mathrm{dafb}$, higher values of soluble solids were found in apples under white nets compared with black nets $(P \leqslant 0.05)$. At commercial harvest (162 dafb), the total soluble solid content was higher in apples under white nets $(P \leqslant$ $0.05)$, than in apples under black nets $\left(16.8 v s .15 .4^{\circ}\right.$ Brix, respectively). However, when comparing total soluble solids in apples at the beginning of the climacteric rise (162 and 154 dafb, respectively), no significant differences were observed between black- and white-net apples. This could indicate that the netting color does not affect the soluble solid content at the same ripening point, but accelerates (white net) or delays (black net) ripening of the fruits, probably due to the difference in light incidence under the nets (figure 1). According to Robinson et al. [16], sunlight incidence correlates positively with apple soluble solid and total solid contents. According to Solomankhin and Blanke [15], apples from trees under redwhite and white hail nets present more soluble solids and advanced starch breakdown compared with apples from trees under green-black and red-black hail nets for both the 'Fuji' and 'Pinova' cultivars. This was attributed to higher photosynthetically active radiation, better light absorption by the leaves, and enhanced synthesis of photo-assimilates when using white and red-white hail nets $[21,22]$.

\subsection{Color and firmness}

Skin color is one of the most important characteristics of apple appearance [23]. Color changes are associated with ripening, which is accompanied by changes in pigments such as chlorophyll and carotenoid content $[24,25]$. Chlorophyll is responsible for the green color of apple skin [26,27].

Hue values changed from green to yellow in both treatments as apple maturation advanced (figure 3A). From 134 to $168 \mathrm{dafb}$, significant differences in ${ }^{\circ} \mathrm{Hue}$ were found between white-net apples and black-net apples $(P \leqslant 0.05)$, with white-net apples showing lower ${ }^{\circ}$ Hue values (a more yellow color). At commercial harvest time (162 dafb), significant differences were observed between treatments $(P \leqslant 0.05)$. The black net $\left(110^{\circ} \mathrm{Hue}\right)$ delayed the development of yellow color of the fruit compared with the white net $\left(107^{\circ} \mathrm{Hue}\right)$, keeping a greener color on the fruit. However, when comparing the skin color on apples under black or white nets at the beginning of the climacteric rise (162 and 154 dafb, respectively), no significant differences were observed. This may suggest an increase in the apple maturation rate when a white net is used (higher PAR), compared with a black net; suggesting there is no effect of net color on apple skin color at the same maturity stage. According to Lancaster [28], color development in apples is a light-dependent process.

According to Solomakhin and Blanke [15], the green spot on 'Fuji' apple skin showed a more saturated green coloration in green-black hail net apples, when compared with red-black, red-white and white hail net apples. Amarante et al. [29] found higher ${ }^{\circ} \mathrm{Hue}$ values in 'Fuji' apples from trees covered by nets. Guerrero et al. [1] and Romo et al. [4] found that the ${ }^{\circ} \mathrm{Hue}$ of 'Redchief Delicious' and 'Starkrimson' apples was affected by hail net color. According to Lancaster [28] and Campbell and Marini [30], low light intensity reduces color development in red apple cultivars, because during ripening carotenoid pigments are synthesized and chlorophylls are degraded [31]. 
During ripening there is a natural decline in firmness caused by changes in the cell wall composition. Pectin is the main polysaccharide present in the cell wall, giving apples firmness. Apple tissue becomes less firm with the advancing of ripening, due to the increased pectinase activity. At a more mature state, there is a more rapid degradation of pectin. Figure $3 B$ shows the effect of black nets and white nets on apple firmness. As apple maturation advanced, firmness decreased, in both treatments. From 133 dafb to 154 dafb, no significant differences were found in apple firmness between treatments $(P \leqslant 0.05)$. However, after 162 dafb lower firmness values were observed in white-net apples compared with black-net apples. The values for pulp firmness showed that the strength of penetration required by the fruits protected by white nets $(58.2 \mathrm{~N})$ was significantly lower $(P \leqslant 0.05)$ than that required by apples protected under black nets $(63.1 \mathrm{~N})$ at commercial harvest (162 dafb). Studies on 'Fuji' apple showed that hail nets delay ripening, and consequently delay apple picking [32]. According to Robinson et al. [16], the percentage of full sunlight incidence correlates negatively with fruit firmness. This coincides with Doud and Ferree, Gardner and Fletcher, and Widmer [33-35], who observed that apples grown under netting were firmer than uncovered ones.

When comparing the firmness of apples under black or white nets at the beginning of the climacteric rise (162 and 154 dafb, respectively), no significant differences were observed. This indicates that the color of the net accelerates (white net) or delays (black net) the ripening rate, with no effect of net color on the firmness of apples at the same maturity stage.

\subsection{Aroma volatile production}

Apple flavor is one of the main quality attributes in this fruit, and it is defined largely by aroma volatile compounds. There are three major chemical groups in apple volatile compounds: aldehydes, alcohols and esters [36]. Aroma compound production is closely linked to the apple maturation process [37]. Figure 4 shows how the volatile compound concentration increased as the dafb of apples increased.

The synthesis of aldehydes is considered to be the first step in the volatile compound synthesis, followed by alcohols, and lastly by esters [38]. Aldehydes are the most dominant aroma volatiles detectable in intact immature apple fruit [39], and they provide apples with green fresh, aromatic, fatty green and green fruity notes $[37,40,41]$. Hexanal and 2-hexenal have been considered as two of the most important constituents of apple-like aroma [42]. In the present work no differences in hexanal and 2-hexenal were found between treatments at commercial harvest (162 dafb). Also, when comparing aldehydes at the beginning of the climacteric rise (162 and 154 dafb, respectively; the same ripening point), no significant differences were seen in apples under black or white nets $(P \leqslant 0.05)$.

Alcohols are found in a greater concentration in ripe apple fruit [43], and these are ester precursors. Alcohols are found in apples at a percentage between $6-16 \%$ depending on the variety. The alcohols with the greatest impact on apple aroma are 1-hexanol, 1-butanol and 2-methyl 1-butanol [44]. When comparing these compounds in apples at the same point of commercial harvest (162 dafb), significantly higher differences were observed $(P \leqslant 0.05)$ in the contents of 1 -hexanol, $8.0 \mathrm{vs}$. $4.4 \mathrm{mg} \mathrm{L}^{-1}$, 1-butanol, 14.6 vs. $8.5 \mathrm{mg} \mathrm{L}^{-1}$, and 2 methyl-1 butanol, 6.2 vs. $2.7 \mathrm{mg} \mathrm{L}^{-1}$ of apples under white vs. black nets, respectively. However, when comparing these alcohol contents in apples under black or white nets at the beginning of the climacteric rise (162 and 154 dafb, respectively), no significant differences were shown $(P \leqslant 0.05)$. The concentration of the alcohols studied showed higher values in apples under white nets when compared with apples under black nets, at commercial harvest. This suggests that the black color delays the apple ripening rate, and hence the synthesis of these compounds. This is supported by the fact that apples under black nets reached the same concentration of aroma volatiles as whitenet apples a week later. This delay may be due to the difference in the amount of light received by the fruits under the different nets (figure 1). Probably light accelerated the synthesis of ethylene in the fruit, since the beginning of the climacteric rise was a week earlier in white-net apples, which received more light. It has been reported that aroma volatile production is closely regulated by ethylene due to its strong impact on the enzymes involved [45]. Defilippi et al. [46] found that volatile compounds are directly related to ethylene production; as the production of ethylene increases, the concentration of volatile compounds is also greater. Esters are the key aroma volatiles that give flavor to mature apples [47]. According to Fellman et al. [37], butyl acetate, 2-methyl butyl acetate and hexyl acetate are considered the major contributors to the characteristic apple-like aroma and flavor in most apple cultivars, giving the distinctive sweet and fruity smell $[20,37,41,48]$. When comparing butyl acetate, 2-methyl butyl acetate and hexyl acetate produced by apples under white net and black nets at commercial harvest (162 dafb), significant differences were found $(P \leqslant 0.05)$ in 2 methyl-butyl acetate contents $\left(0.475 \mathrm{mg} \mathrm{L}^{-1}\right.$ vs. $0.184 \mathrm{mg} \mathrm{L}^{-1}$ ), the apples protected under white nets presenting greater concentrations. No significant differences were found in hexyl acetate and butyl acetate between treatments at commercial harvest. When comparing these esters in apples under black or white nets at the beginning of the climacteric rise (162 and 154 dafb, respectively), no significant differences were shown $(P \leqslant 0.05)$ in either butyl acetate, 2 -methyl butyl acetate or hexyl acetate.

No previous study has been conducted on the effects of the use of hail nets on volatile compounds, although some research on the effects of light on these compounds has already been reported. A study by Miller et al. [49] showed the effect of light intensity on apple esters with the following treatments: 100 (full sun), 53, 19 and $<1 \%$. These authors found that volatile ester emissions were strongly affected by light exposure, with maxima occurring at $53 \%$ full sun.

\section{Conclusion}

There are no differences in fruit weight and diameter of apples grown under white or black nets at commercial harvesting. However, changes in TSS, TA, color, firmness and volatile 


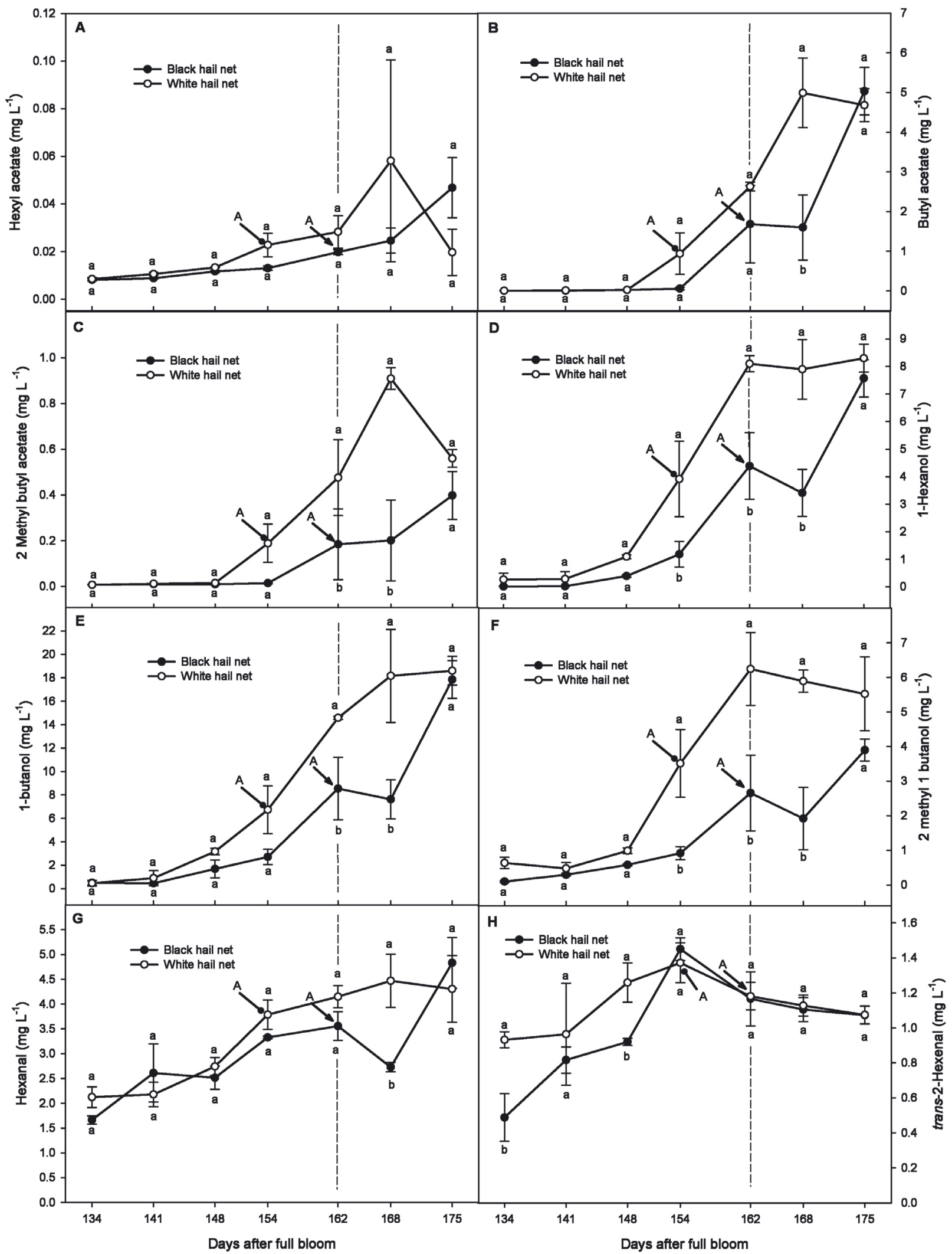

Figure 4. Effect of the hail net color on aroma volatile production of 'Golden Delicious' apples during growth and development. The vertical bars represent means \pm SE. Different lower-case letters show statistical differences within the same harvest time; different capital letters show statistical differences in the climacteric rise (by Tukey's test, $P \leqslant 0.05$ ). $\rightarrow$ climacteric rise for white-net apples $(154$ dafb), $\rightarrow$ climacteric rise for black-net apples (162 dafb), - - - commercial harvest (162 dafb). 
compounds are delayed by one week in black-net apples, when compared with white-net apples, the same time that the climacteric rise is delayed. The results of this study suggest that the black net color affects the apple maturation rate, delaying physiological maturation, but not affecting apple physical development. Therefore, fruits under black netting might be left on the tree (one week) for a late harvest. Further studies are needed in order to determine the effect of the netting color on apple quality during storage.

Acknowledgements. This research was supported by the Mexican National Council of Science and Technology (CONACYT) and Chihuahua State Government, through the CHIH-2008-C01-92083 FOMIX grant. The authors thank David Berlanga and Alejandro Romo for their technical assistance, Grupo La Norteñita S.A. for providing fruit samples for this study and the Unión Agricola Regional de Fruticultores del Estado de Chihuahua UNIFRUT.

\section{References}

[1] Guerrero V.M., Orozco J.A., Romo A., Gardea A.A., Molina F.J., Sastre B., Martínez J.J., The effect of hail nets and ethephon on color development of 'Red Chief Delicious' apple fruit in the highlands of Chihuahua, México, J Am Pomol Soc. 56 (2002)132-135.

[2] Tasin M., Demaria D., Ryne C., Cesano A., Galliano A., Anfora G., Ioriatti C., Alma A., Effect of anti-hail nets on Cydia pomonella behavior in apple orchards, Entomol. Exp. Appl. 129 (2008) 32-36.

[3] Botzen W.J.W., Bouwer L.M., Van den Bergh J.C.J.M., Climate change and hailstorm damage: Empirical evidence and implications for agriculture and insurance, Resour Energy Econ. 32 (2010) 341-362.

[4] Romo-Chacon A., Orozco-Avitia J.A., Gardea A.A., GuerreroPrieto V., Soto-Parra J.M., Hail net effect on photosynthetic rate and fruit color development of 'Starkrimson' apple trees, J. Am. Pomol. Soc. 61 (2007) 174-178.

[5] Widmer A, Light intensity and fruit quality under hail protection nets, Acta Hortic. 557 (2001) 421-426.

[6] Middleton S., McWaters A., Hail netting of apple orchards - Australian experience, The Compact Fruit Tree 35 (2002) 51-55.

[7] Stampar F., Veberic R., Zadravec P., Hudina M., Usenik V., Solar V.A., Osterc G., Yield and fruit quality of apples cv. 'Jonagold' under hail protection nets, Eur. J. Hortic. Sci. 67 (2002) 205-210.

[8] Reay P.F., Fletcher R.H., Thomas V.J., Chlorophylls, carotenoids and anthocyanin concentrations in the skin of 'Gala' apples during maturation and the influence of foliar applications of nitrogen and magnesium, J. Sci. Food Agr. 76 (1998) 63-71.

[9] Funke K., Blanke M.M., Can reflective ground cover enhance fruit quality and colouration? J. Food Agric. Environ. 3 (2005) 203-206.

[10] Olivas G.I., Mattinson S., Pérez J., Molina J., Fellman J., Mattheis J., Quality characteristics of Red and Golden Delicious apples during maturation: A comparison between Mexican and Pacific Northwest Apples, HortScience 43 (2008) 1280.
[11] Salas N.A., Molina-Corral F.J., González-Aguilar G.A., Otero A., Olivas G.I., Volatile production of "Golden Delicious" apples during storage is affected by aminoethoxy vinilglycine, Sci. Hortic. 130 (2011) 436-444.

[12] Smit A., Apple tree and fruit responses to shade netting, University of Stellenbosch, Stellenbosch, South Africa, Thesis, 2007, 272 p.

[13] Bepete M., Lakso A.N., Differential effects of shade on early-season fruit and shoot growth rates in empire apple, HortScience. 33 (1998) 823-825.

[14] Knee M., Pome Fruit: Biochemistry. In: Seymour GB, Taylor JE, Tucker GA (Eds.), Biochemistry of fruit ripening Chapman \& Hall University Press, Cambridge, UK, 1993.

[15] Solomakhin A., Blanke M.M., Can coloured hail nets improve taste (sugar, sugar:acid ratio), consumer appeal (colouration) and nutritional value (anthocyanin, vitamin C) of apple fruit?, LWT - Food Sci. Technol-Leb. 43 (2010) 1277-1284.

[16] Robinson T.L., Seeley E.J., Barritt B.H., Effect of light environment and spur age on 'Delicious' apple fruit size and quality, J. Am. Soc. Hortic Sci. 108 (1983) 855-861.

[17] Wagenmakers P., Tazelaar M., Resulting light reduction determines the future of hail nets in the Netherlands, Fruitteelt. 89 (1999)10-11.

[18] Iglesias I., Alegre S., The effect of anti-hail nets on fruit protection, radiation, temperature, quality and profitability of 'Mondial Gala' apples, J. Appl. Hortic. 8 (2006) 91-100.

[19] Kader A.A., Quality and its maintenance in relation to the postharvest physiology of strawberry. In: Luby JJ \& Dale A (Eds.), The Strawberry into the 21st Century. Timber Press, Portland, OR, 1991.

[20] Yahia E.M., Apple flavor, horticultural reviews. 16 (1994) 197-234

[21] Solomakhin A., Blanke M.M., Coloured hail nets alter light transmission, spectra and phytochrome, as well as vegetative growth, leaf chlorophyll and photosynthesis and reduce flower induction of apple, Plant Growth Regul. 56 (2008) 211-218.

[22] Johnson R.S., Lakso A.N., Carbon balance model of a growing apple shoot: II. Simulated effects of light and temperature on long and short shoots, J. Am. Soc. Hortic. Sci. 111 (1986) 164-169.

[23] Wills R.B.H., Lee T.H., Graham D., McGlasson W.B., Halle G., Postharvest. An introduction to the physiology and handling of fruit and vegetables, AVI publishing, Westport, Conn. 1981.

[24] Gross J., Pigments in fruits, Academic Press, London, 1987.

[25] Knee M., Anthocyanin, carotenoid and chlorophyll changes in the peel of Cox's Orange Pippin apples during ripening on and off the tree, J. Exp. Bot. 23 (1972) 184-196.

[26] Stanley J.K., Preharvest factors affecting appearance, Postharvest Biol. Tec. 15 (1999) 233-247.

[27] Jakopic J., Stampar F., Veberic R., The influence of exposure to light on the phenolic content of 'Fuji' apple. Sci. Hortic. 123 (2009) 234-239.

[28] Lancaster J.E., Regulation of skin color in apples, CRC Cr Rev Plant Sci. 10 (1992) 487-502.

[29] Amarante C.V.T., Steffens C.A., Argenta L.C., Yield and fruit quality of Gala and Fuji apple trees protected by white ant-hail net, Sci. Hortic. 129 (2011) 79-85.

[30] Campbell J., Marini R., Light environment and time of harvest affect Delicious apple fruit quality characteristics, J. Am. Soc. Hortic. Sci. 117 (1992) 551-557.

[31] Awad M.A., Wagenmakers P.S., de Jager A., Effects of light on flavonoid and chlorogenic acid levels in the skin of 'Jonagold' apples, Sci. Hortic. 88 (2001) 289-298. 
[32] Jakopic J., Veberic R., Stampar F., The effect of reflective foil and hail nets on the lighting, color and anthocyanins of 'Fuji' apple, Sci. Hortic. 115 (2007) 40-46.

[33] Doud D.S., Ferree D.C., Influence of altered light levels on growth and fruiting of mature 'Delicious' apple trees, J. Am. Soc. Hortic. Sci. 105 (1980) 325-328.

[34] Gardner R.A.W., Fletcher C.A., Hail protection systems for deciduous fruit trees, Deciduous Fruit Grower 40 (1990) 206-212.

[35] Widmer A., Light conditions, assimilation and fruit quality under hail nets, Obst und Weinbau 133 (1997) 197-199.

[36] Defilippi B.G., Manriquez D., Luengwilai K., GonzalezAgüero M., Aroma Volatiles: Biosynthesis and Mechanisms of Modulation During Fruit Ripening, Adv. Bot. Res. 50 (2009) $1-37$.

[37] Fellman J.K., Miller T.W., Mattinson D.S., Mattheis J.P., Factors that influence biosynthesis of volatile flavor compound in apple fruits, HortScience 35 (2000) 1026-1033.

[38] Pérez A.G., Sanz C., Formation of fruit flavour. In: Brückner B, Wyllie SG (Eds.), Fruit and vegetable flavor CRC Press Boston, New York, Washington DC and Woodhead Publishing Limited, Cambridge, England, 2008.

[39] De Pooter H.L., Van Acker M., Schamp N.M., Aldehyde metabolismo and the aroma quality of stored Golden Delicious apples, Phytochemistry 26 (1987) 89-92.

[40] Panasiuk O., Talley F.B., Sapers G.M., Correlation between aroma and volatile composition of McIntosh apples, J. Food Sci. 45 (1980) 989-991.
[41] Dimick P.S., Hoskin J.C., Review of apple flavour-state of the art, CRC Cr. Rev. Food Sci. 18 (1983) 387-409.

[42] Flath R.A., Black D.R., Guadagni D.G., McFadden W.H., Schultz T.H., Identification and organoleptic evaluation of compounds in Delicious apple essence, J. Agric. Food Chem. 15 (1967) 29-34.

[43] Dixon J.E., Hewett E., Factors affecting apple aroma/flavour volatile concentration: a review, New Zeal. J. Crop Hort. 28 (2000) 155-173.

[44] Espino-Díaz, M., Olivas, G.I., Biochemistry of apple aroma. Food Technol. Biotechnol. Submitted.

[45] Halder-Doll H., Bangerth F., Inhibition of autocatalytic C2H4biosynthesis by AVG applications and consequences on the physiological behaviour and quality of apple fruits in cool storage, Sci. Hortic. 33 (1987) 87-96.

[46] Defilippi B.G., Dandekar A.M., Kader A.A., Impact of suppression of ethylene action or biosynthesis on flavor metabolites in apple (Malus Domestica Borkh) fruits, J. Agric. Food Chem. 52 (2004) 5694-5701.

[47] Salas N.A., Olivas G.I., El aroma de la manzana, Interciencia. 36 (2011) 265-271.

[48] Cunnigham D.G., Acree T.E., Barnard J., Butts R., Braell P., Charm analysis of apple volatiles, Food Chem. 19 (1986) 137-147.

[49] Miller T.W., Fellman J.K., Mattheis J.P., Mattinson D.S., Factors that influence volatile ester biosynthesis in 'Delicious' Apples, Acta Hortic. 464 (1998) 195-200. 
Resumen - Introducción. Estudio comparativo de los efectos de las mallas antigranizo negras o blancas en la calidad de la manzana 'Golden Delicious'. El uso de mallas antigranizo es una práctica muy común en México, con el fin de proteger las manzanas durante su desarrollo y maduración en el árbol. Esta práctica puede causar cambios en la calidad de la fruta así como en la composición del aroma. El presente trabajo evaluó el efecto del color de la malla antigranizo sobre la calidad de la manzana y la producción de compuestos volátiles del aroma. Materiales y métodos. Árboles de la variedad 'Golden Delicious' fueron cubiertos con malla blanca o negra. Muestras de manzana fueron semanalmente cosechadas durante los meses de agosto a octubre y analizada por su peso, diámetro axial y ecuatorial, color ( ${ }^{\circ} \mathrm{Hue}$ ), firmeza, sólidos solubles totales (TSS), acidez, producción de etileno (EC) y compuestos volátiles del aroma. La radiación fotosintéticamente activa (PAR) fue medida cada diez días bajo la malla y fuera de la malla. Resultados y discusiones. La calidad de la manzana se vio afectada por el color de la malla antigranizo. La malla negra retardó el desarrollo de la madurez y de la calidad en una semana, en comparación con la malla antigranizo blanca. La PAR fue $18 \%$ menor bajo malla negra que bajo malla blanca. Los parámetros de calidad en el punto de madurez comercial (162 días después de plena floración) de las manzanas bajo malla blanca mostraron 7\% menor firmeza, 11.1\% menor acidez, 8.3\% mayor cantidad de TSS, y una coloración más amarilla en comparación con las manzanas bajo malla negra. Además, las manzanas bajo malla blanca mostraron una mayor concentración de los principales compuestos volátiles del aroma ( $\mu g \mathrm{~L}^{-1}$ ), 1-hexanol (8.09 vs 4.38), 2-metil-1butanol (6.24 vs 2.65) y 2-metil-butil acetato (0.47 vs 0.16$)$. No se observó diferencia significativa entre las manzanas bajo malla blanca y malla negra al mismo estado de madurez (al inicio del climaterio) en lo referente a TSS, acidez, firmeza y compuestos volátiles del aroma. Conclusión. La funcionalidad de las mallas antigranizo va más allá de proteger los árboles del daño por granizo; la malla antigranizo afecta la velocidad de maduración de la manzana, la calidad y la producción de compuestos volátiles del aroma.

Palabra clave: México / manzana / Malus domestica / malla antigranizo / radiación fotosintéticamente activa / volátiles del aroma

Cite this article as: Veronica Ordóñez, Francisco Javier Molina-Corral, Claudia Lizeth Olivas-Dorantes, Juan Luis Jacobo-Cuéllar, Gustavo González-Aguilar, Miguel Espino, David Sepulveda, Guadalupe Isela Olivas1mm. Comparative study of the effects of black or white hail nets on the fruit quality of 'Golden Delicious' apples1mm. Fruits 71(4) (2016) 229-238. 